\title{
The Role of Shelterbelts in Vegetation Development of Desert Prone Area of Yobe State, Nigeria
}

\author{
Adesina, F. A. ${ }^{1} \&$ Gadiga, B. L. ${ }^{2}$ \\ ${ }^{1}$ Department of Geography, Obafemi Awolowo University, Ile-Ife, Nigeria \\ ${ }^{2}$ Department of Geography, Adamawa State University, Mubi, Nigeria \\ Correspondence: Gadiga, B. L., Department of Geography, Adamawa State University, Mubi, Nigeria. Tel: \\ 234-806-430-6660. E-mail: bulga_mi@yahoo.com
}

\author{
Received: July 21, 2014 Accepted: August 19, 2014 Online Published: November 18, 2014 \\ doi:10.5539/jgg.v6n4p109 URL: http://dx.doi.org/10.5539/jgg.v6n4p109
}

\begin{abstract}
Environmental degradation is a major contemporary globally issue that is bedeviling most parts of the arid environment. This is due to the several centuries of poor management of the earth's natural resources, and the increasing pressure associated with rapid population growth. This study assesses the influence of some selected shelterbelts in arid environment of Yobe State, Nigeria on vegetation characteristics. This is with intention of identifying its significance in fighting desert encroachment. In the selected shelterbelts, sample plots (quadrats) measuring $30 \mathrm{~m}^{2}$ in dimension was systematically located at an interval of 200 meters. On the adjoining areas of the shelterbelt, control quadrats of similar size were located at the same interval and at a distance of 100 meters from the belt. The vegetation characteristics analyzed in this study include height, diameter, density, frequency and diversity. SPSS, CANOCA and PAST ecological software were used in analyzing the data collected. The result shows that there is significant difference $(\mathrm{P}<0.005)$ between all the vegetation characteristics in the shelterbelt sites and the control sites except species diversity. This shows that shelterbelts are necessary tool in fighting desertification in the area as they enhance the vegetation status thereby protecting the soil against wind erosion which is one of the major ecological problems of desertification.
\end{abstract}

Keywords: desertification, wind erosion, shelterbelt, Simpson's index, vegetation ordination

\section{Introduction}

Environmental degradation is a major contemporary globally issue that is bedeviling most parts of the arid environment. This is due to the several centuries of poor management of the earth's natural resources, and the increasing pressure associated with rapid population growth. Degradation of natural resources especially vegetation is most felt in the fragile environment of arid regions of the world which is home to several millions of people (United Nations Environment Programm (UNEP), 2008; Federal Ministry of Environment (FME), 2008). While drought and desertification are largely natural occurrence (Oladipo, 1993) these phenomena are significantly exacerbated by anthropogenic factors particularly farming, grazing and tree felling.

Desertification, as defined in Chapter 12 of "Agenda 21", Rio declaration on environment and development "is the degradation of the land in arid, semi-arid and sub-humid dry areas resulting from various factors, including climatic variations and human activities" (UNICED, 1992). It reduces the ability of land to support many life forms, limiting biodiversity and constraining socio-economic activities and development. It also stimulates accelerated soil erosion and deposition particularly by wind. Open land with little or no vegetal cover is highly vulnerable to both wind and water erosion (Cao, et al. 2008). In the absence of vegetation, rain water is mainly disposed as runoff due to minimal infiltration rate. This further constrains the growth and productivity of plants. Even long-lived plants: trees, shrubs and other perennials that would normally survive droughts eventually find survival an insurmountable challenge. A reduction in plant cover also results in lowering the quantity of humus in the soil, and plant productivity drops further (Adesina, 2008). As protective plant cover disappears, the probability of flash floods becomes higher and further degradation occurs. Thus, in general terms, desertification is self-reinforcing, that is, once the process starts it creates conditions for self sustenance.

Desertification and drought have severe impacts on food security, livelihood, socio-economic and cultural activities of the region where they occur. It is accompanied by a reduction in the natural potential of the land and 
depletion in surface and ground-water resources. Desertification is not only a feature of natural deserts, but also takes place on land which is exposed to persistent drought and human pressure. In West Africa and in Nigeria in particular, food insecurity associated with desertification is mounting (UNEP, 2008). This is causing significant socio-economic challenges including mass movement of people from arid environment and reduced supply of food as well as disruption in the economic and social activities of people living in semi-arid environment (National Action Plan (NAP), 2007). Shelterbelt has been adjudged as one of the effective ecological means of contending the effects of desertification in an arid environment. Shelterbelts are rows of trees planted perpendicular to the direction of the prevailing winds to reduce their velocities. Igugu and Osemeobo (1991) reported that between 1963 and 1989 over 236,500 hectares of shelterbelts were established in the States threatened by desertification in Nigeria. This coverage of shelterbelts apart from being inadequate has sadly been allowed to deteriorate by the activities of farmers, loggers and fuelwood extractors. The Nigerian Forest Policy specifies that at least $20 \%$ of the country's total land area should be reserved as forest estates to effectively fight environmental degradation (Odigie and Obiaga, 1991; FAO, 2005). Considering the magnitude of shelterbelt development needed to fight the menace of desertification in Nigeria, both government and people living in the arid and semi-arid region need to actively rise up to the challenges.

In semi-arid regions, the short rainy season provides limited opportunities for plants to grow. This can however be exploited to grow and nurture adaptable varieties of plants in afforestation projects. Afforestation is the deliberate planting of trees where it has not existed before or where original tree cover had been removed. Without afforestation and support for the trees, it is almost impracticable to have re-establishment of tree cover in most tropical arid lands. Growing seasons are short and wild grazing is uncontrolled. In the event that natural regrowths happen, removal by grazing animals makes the plants short-lived.

Afforestation can be achieved by establishing shelterbelts, increasing densities of farm-trees, planting live fences and by establishing woodlot (Igboanugo, 1991). Among these afforestation strategies, shelterbelts are the most effective and environmentally friendly approach to achieving success in combating desertification in the arid and semi-arid environments. Shelterbelts are established both to ensure their survival and enhance their capacity to yield optimum environmental benefits. Apart from the ecological and socio-economic benefits that they provide, shelterbelts reduce wind velocities as well as modify micro-climates (Ojo, et al., 1987; Igugu and Osemeobo, 1991; Wang and Takle, 1996; Mohammed, et al., 1996; Cornelis and Gabriels, 2005; Torita and Satou, 2007). In particular, the planting of shelterbelts in rows perpendicular to the direction of the prevailing winds, makes it possible for the trees to act as windbreak and so protect vegetation, and soils on the lee side against wind damages. Shelterbelt also improves the microclimatic conditions by the cooling effect of transpiration of the trees and conservation of available water resources. In this way, shelterbelts provide 'safe sites' for other plants to thrive through the process of establishment and succession (Pascal, 2003). They can thus become "growth" areas for the expansion of vegetation cover in the area.

Among the specific objectives of establishing shelterbelts in Nigeria as highlighted by Igugu and Osemeobo, (1991) are to:

i. Create windbreaks against high winds, check moving sand dunes and create conducive microclimate for sustainable agricultural production and recreation.

ii. Provide habitat for small animals including migratory birds;

iii. Improve soil productivity and carrying capacities of biotic and abiotic resources.

Shelterbelts are established on communal lands and in forest reserves. The traditional shelterbelts in Nigeria are composed of pure stands of Azadirachta indica (neem tree) or Eucalyptus camaldulensis with ten rows of trees in an escapement of $2.5 \mathrm{~m} \times 2.5 \mathrm{~m}$ to give a size of $200 \mathrm{~m} \times 30 \mathrm{~m}$ per belt (Okefiena, 1988).

Shelterbelts are being used to curb the expansion of desert condition and reduce the subsisting impacts of aridity in northern region. It is crucial that these shelterbelts are successfully established otherwise the objectives behind them may never be realized. This study assesses the influence of some selected shelterbelts in arid environment of Yobe State, Nigeria on vegetation characteristics. This is with intention of identifying its significance in fighting desert encroachment.

\section{The Study Area}

This study was conducted in the northern parts of Yobe State in an area that is highly vulnerable to desertification. The area has witnessed huge investment in shelterbelt projects in order to check the menace of desert encroachment in the area.

The area is located between latitude $10^{\circ} 30^{\prime} \mathrm{N}$ and $13^{\circ} 27^{\prime} \mathrm{N}$, and longitude $9^{0} 35^{\prime} \mathrm{E}$ and $12^{\circ} 30^{\prime} \mathrm{E}$ (Figure 1). It is 
a part of the Sahelian region of Nigeria where desertification is threatening the ecology and livelihood of the inhabitants of the area (UNESCO, 2000; UNDP, 2009; Orounye, 2009). Yobe State is bordered to the North by Niger republic, to the East by Borno State, to the West by Jigawa and Bauchi States and to the South by Gombe and Borno States. It has a land area of $47,153 \mathrm{sq} . \mathrm{km}$ and a population of 2.7 million based on 2006 National Census.

Yobe State like other parts of the Sahel savanna has clearly defined wet and dry season largely determined by the properties and movement of the Inter-tropical Convergence Zone (ITCZ). Much of the climatic condition of the State is that of general northern Nigeria's climate.

The movement of the ITD controls the durations and amounts of rainfall received in most parts of West Africa including the study area. The area generally receives between $250-500 \mathrm{~mm}$ of rainfall and lasting for three months (Oruonye, 2009). Since the last century, there have been more frequent droughts than what historical records indicate. Notable events are the droughts of 1913-14, 1931-32, 1942-43, 1972-73, and 1983-84 (Odekule, et al., 2008). This trend has contributed to the near disappearance of the Lake Chad (e.g. Dami, 2008). As observed by Bovill (1921) the northern parts of Nigeria suffered remarkable drought conditions in the first and second decades of the $19^{\text {th }}$ Century so much so that the Sahara desert expanded significantly into large areas of the Sudan. The trend had continued into most part of the $20^{\text {th }}$ Century (Dami 2008). The region received some of its lowest rainfall in 1973 when it had less than 40 per cent of its mean annual rainfall (Oguntoyinbo, 1983).

Temperatures are generally high throughout the year, although there are significant variabilities. The highest air temperatures are normally in April before the onset of the rains and the minimum in December during the harmattan. The area has a mean maximum of $40.6^{\circ} \mathrm{C}$ and a mean minimum of $12.8^{\circ} \mathrm{C}$ (Oguntoyinbo, 1983). The study area lies within the Sahel- Sudan Savannah belt. It comprise mainly of shrubs intersperse by few trees. The native species of trees commonly found in the area include Acacia spp, Balanites aegyptiaca, Adasonia digita, doum palm (Hyphaenae thebaica) and exotic species include neem trees (Azadirachta indica), Eucalyptus camaldulensis and Prosopis Juliflora.

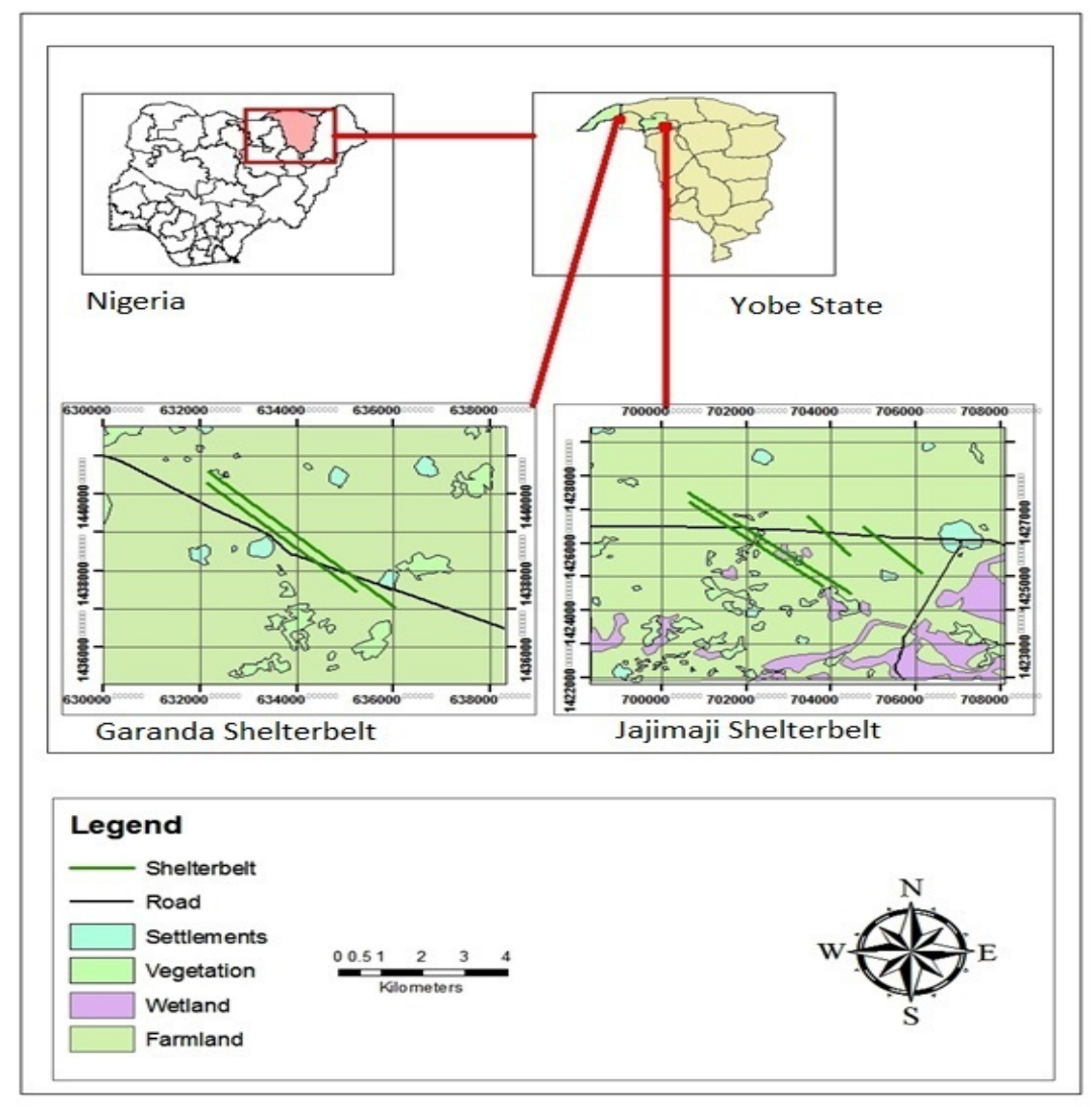

Figure 1. The study area 


\section{Methodology}

Four shelterbelts planted with a variety of trees at an interval of $3 \times 3$ meters were purposively selected for the study. The shelterbelts are designed to have four rows of Acacia senegal or Acacia sayel (two rows on both sides) and six rows of Azadirachta indica in the middle making a total of 10 rows of trees per belt (Okefiena, 1988). The shelterbelts were established by the Federal Government of Nigeria under the Nigeria Second Forestry Development Project (Forestry II Project) in 1987 to check the southward expansion of the Sahara desert in the area. The selected belts measured between 4 and 5 kilometers in length and are located in Machina and Karasuwa Local Government Areas of Yobe State. The two shelterbelts selected in Machina LGA are those that are located in Garanda village. There are established at an interval of 200 meters away from each other with an approximate length of five kilometers. The other two shelterbelts selected were those located in Jajimaji, (Karasuwa LGA) and have similar design with that of Garanda site. These shelterbelts were selected for the study because of their relative length and continuous span as well as their successes despite the increasing pressures from pastoralists and crop farmers. Control sites were also selected on the adjoining sides of each shelterbelt.

In the selected shelterbelts, sample plots (quadrats) measuring $30 \mathrm{~m}^{2}$ in dimension was systematically located at an interval of 200 meters. Wherever there was a break in the stretch of the shelterbelt to the effect that the systematic location cannot be implemented, the quadrat was located at the continuation of the shelterbelt and the systematic procedure was then initiated again. On the adjoining areas of the shelterbelt, control quadrats of similar size were located at the same interval and at a distance of 100 meters from the belt (Figure 2). Some previous studies which came up with desirable results of practical applications have applied similar sampling procedures (e.g. Szajdak et al., 2005). The quadrat size chosen has been tested with a measure of success in different parts of the tropics (e.g. Adejuwon and Adesina 1985; 1988).

Figure 2 shows how the plots were located within the shelterbelts and the adjoining areas. Geographic locations of the centre of each of the selected plots were obtained with a hand-held GPS.

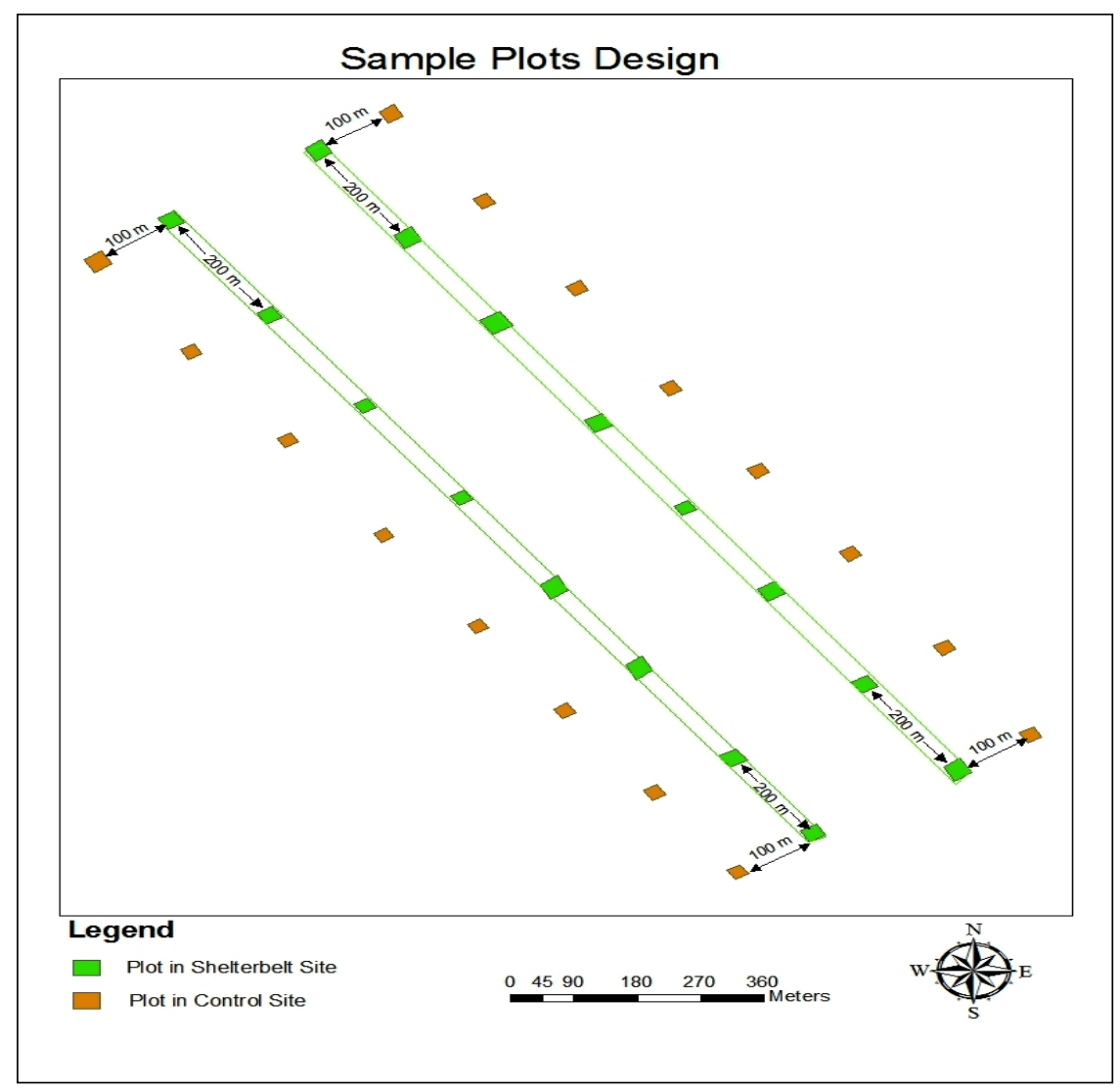

Figure 2. A Diagrammatic Illustration of the location of the selected Sample plots 
In each of the $30 \times 30 \mathrm{~m}^{2}$ plots, all the species of plants including the herbs and creeping species were identified and counted to determine the species density. A tree was operationally defined as any woody plant with erect habit and has a height of $1.5 \mathrm{~m}$. Tree girths at breast height were measured with a measuring tape. Over-bark measurement of tree circumference is the easiest measurement used in determining tree diameter; the measurement is taken at breast height $(1.3 \mathrm{~m})$ from the base of the tree and then convert to tree diameter by dividing the circumference by $3.147(\pi)$. It is quick, inexpensive and closely correlate with tree volume or biomass. Readings from hand held abney level were taken on the trees. These were taken from distances ranging from 10-15 meters for the measurement of tree height. The readings were used to compute tree heights in the laboratory using equation (Eq.) 1

$$
\begin{gathered}
\text { Height }=(\mathrm{D} * \tan \Theta)+\mathrm{Ob} \\
\mathrm{D}=\text { horizontal distance } \\
\Theta=\text { angle of elevation } \\
\mathrm{Ob}=\text { observer's height }
\end{gathered}
$$

The abundance and richness of species was measured using diversity index. Abundance is the evenness of different species making up the richness of an area and richness is the number of species in a sample. In general, as the abundance and richness of the species increase the diversity tend to increase. There are many indices of vegetation diversity used in vegetation analysis (Gadiga, 2012). Simpson's Index was chosen for this study because it has been reported as a very robust diversity index.

$$
\text { The Simpson's index is given as: } D=\frac{\sum n(n-1)}{N(N-1)}
$$

Where:

$D=$ diversity index

$N=$ total number of individuals of all species

$n=$ number of individuals of a specific species

Simpson's Index of Diversity $=1-D$

The value of this index ranges between 0 and 1.0 means lower diversity and 1 higher diversity.

The ANOVA results were achieved using SPSS software (version 17), CANOCA software was used in species and sample ordination while the diversity index was implemented using PAST software.

\subsection{Vegetation Ordination Techniques}

Ordination is a multivariate technique that projects points onto two dimensional spaces which visually portrays the data for easy interpretation. It is basically used in summarizing community data by producing ordination space in which species and samples that are similar are grouped close to each other while those without similarity are plotted far apart. Ordination techniques were used to correlate vegetation (species) and environment (site). Goodall (1954) define Ordination as "an arrangement of units in a uni- or multi-dimensional order". Ordination emphasized the arrangement of sample unit (stand or species) by individual values rather than group values.

This shows a geometric arrangement where similar stand/species are closer to each other and dissimilar stand/species are far apart. The method has been used by ecologist to study trends in vegetation variation and in identifying environmental gradient. Detrended Correspondence Analysis (DECORANA) is an eigenvector ordination technique which simultaneously ordinates both species and sites by a reiterative weighing procedure (Adejuwon, et al. 1989). Its ability to contain wide variability in data set without any serious interpretation consequences has given it a unique capability as an ordination technique in vegetation analysis. It has been reported by many researchers as one of the best ordination techniques available for highly diversified community and in generating information about vegetation characteristics which can be used to correlate vegetation with other elements of the environment (Adejuwon, et al. 1989; Graae, and Heskjax, 1997; Molder, et al., 2008).

\section{Results and Discussion}

\subsection{Tree Height}

Tree height is an important requirement in designing shelterbelt to reduce wind erosion which is one of the major 
ecological problems of desertification in the arid environments. It increases the capacity of the shelterbelts in protecting areas on their leeward side against desiccating winds. The shelterbelts studied have a relatively homogenous height with variations noticeable between different species used in the establishment of the belts. This is primarily because they were planted at the same period (1987) as it is the common characteristics of monoculture plantation. Table 1 shows the mean height of trees within the sampled plots. The mean height of trees in the shelterbelt plots are 7.49, 7.40, 7.43 and 6.85 meters for the first Jajimaji shelterbelt (JJ1), the second Jajimaji shelterbelt (JJ2), the first Garanda shelterbelt (GD1) and the second Garanda shelterbelt (GD2) respectively while the control plots have the mean values of 3.8 (JJ1 Cont), 4.10 (JJ2 Cont), 3.56 (GD1 Cont) and 2.24 meters (GD2 Cont). The analysis of the individual mean height of species used in the shelterbelt are; Azadirachta indica $7.3 \mathrm{~m}$, Eucalyptus camaldulensis $9.1 \mathrm{~m}$, Prosopis juliflora $5.6 \mathrm{~m}$ and Acacia spp $4.5 \mathrm{~m}$. The belts are designed in a way as to reduce erosion at the base of the taller trees by planting the shorter species (Acacia and Prosopis spp) at the outer row and the taller species (Azadirachta and Eucalyptus) in the middle. The Analysis of Variance (ANOVA) presented in Table 2 shows that there is significant difference between tree heights of shelterbelts with that of the adjacent farmlands $(\mathrm{P}<0.05)$. This should be expected as most of the trees found on the farmlands are constantly being pruned by herdsmen or cut down by fuelwood extractors.

Table 1. Trees Height characteristics

\begin{tabular}{lccc}
\hline Site & Mean & Std. Deviation & Std. Error \\
\hline JJ1 & 7.4917 & 1.59912 & .46163 \\
JJ2 & 7.4000 & .78044 & .22529 \\
GD1 & 7.4333 & .62280 & .17979 \\
GD2 & 6.8500 & .79829 & .23045 \\
JJ1 Cont & 3.8000 & 2.41699 & .69772 \\
JJ2 Cont & 4.1000 & 3.16314 & .91312 \\
GD1 Cont & 3.5583 & 2.75333 & .79482 \\
GD2 Cont & 2.2417 & 2.80890 & .81086 \\
\hline
\end{tabular}

The isolated trees found on the farms provide economic as well as social benefits; the trees non-woody products are normally sold to provide income. They also provide medicine and comfort from the scorching sun. Tree heights provide good understanding of the degree of utilization of vegetal resources by the people living in the area. The reduction in height means that there are some degrees of disturbances taking place in the adjacent farmlands. Farming activities is one of the major disturbances in the study area that contribute to reduction in trees height. The factors responsible include annual clearing of vegetation to create space for crop cultivation. Grazing by domestic animals is another factor in considering the state of vegetation in the area (e.g. Ayuba, 1998). Due to shortage of grasses during the dry season, herdsmen engage in lopping of trees and shrubs to provide feeds for their animals, this too contributes to reduction in tree height which are normally practiced on the adjacent side of the shelterbelts where there is no restriction to tree felling.

Table 1. Comparison of Vegetation Characteristics between Shelterbelt and Control Sites

\begin{tabular}{llrrrrr}
\hline $\begin{array}{l}\text { Vegetation } \\
\text { Characteristics }\end{array}$ & \multicolumn{1}{c}{$\begin{array}{c}\text { Sum of } \\
\text { Squares }\end{array}$} & df & Mean Square & F & Sig. \\
\hline Height & Between Groups & 359.213 & 1 & 359.213 & 80.784 & .000 \\
& Within Groups & 417.978 & 94 & 4.447 & & \\
Tiameter & Total & 777.192 & 95 & & & \\
& Between Groups & 3145.544 & 1 & 3145.544 & 88.602 & .000 \\
& Within Groups & 3337.198 & 94 & 35.502 & & \\
Density & Total & 6482.742 & 95 & & & \\
& Between Groups & 31104.000 & 1 & 31104.000 & 170.863 & .000 \\
& Within Groups & 17111.833 & 94 & 182.041 & & \\
Frequency & Total & 48215.833 & 95 & & & \\
& Between Groups & 11.344 & 1 & 11.344 & 5.173 & .025 \\
& Within Groups & 206.146 & 94 & 2.193 & & \\
\hline
\end{tabular}

Significant at 0.05 level 


\subsection{Tree Diameter}

The mean tree diameter per sample plot is shown in Table 3. The ANOVA result in Table 2 shows that the shelterbelts and control plots are significantly different with respect to diameter $(\mathrm{P}<0.05)$. The reduction in diameter of trees in the control sites is as a result of the same factors responsible for the lower height of trees as mentioned earlier. The result of the standard deviation shows that the control sites have higher standard deviation because of the variations between the trees which were protected by farmers and the rejuvenated trees. Those large trees that were preserved on farms for economic as well as social values were older and bigger than the shelterbelt trees but because the larger trees are few in number or sometimes none existent on the control plots led to reduction in their diameter. Hence, the study show that the shelterbelt sites has more carbon stock than the control sites which by implication means higher capacity for sequestrating carbon dioxide from the atmosphere.

Table 2. Characteristics of Tree Diameter

\begin{tabular}{lccc}
\hline Site & Mean & Std. Deviation & Std. Error \\
\hline JJ1 & 21.2008 & 5.29064 & 1.52728 \\
JJ2 & 17.5733 & 4.14566 & 1.19675 \\
GD1 & 21.7450 & 3.08184 & .88965 \\
GD2 & 18.9983 & 3.23682 & .93439 \\
JJ1 Cont & 9.4542 & 6.02668 & 1.73975 \\
JJ2 Cont & 8.3308 & 6.43077 & 1.85640 \\
GD1 Cont & 9.3450 & 8.16183 & 2.35612 \\
GD2 Cont & 6.5942 & 8.70880 & 2.51402 \\
\hline
\end{tabular}

\subsection{Tree Density}

The determination of tree density is useful in evaluating the number of individuals in a sample plot. Tree density is measured as number of trees per plot (area of sample) and it is also an important requirement in shelterbelt design to check desert encroachment (Cornelis and Gabriels, 2005; Torita and Satou, 2007). This is because tree density can greatly reduce impact of desiccating winds on the environment. Table 4 shows the mean, standard deviation and standard error of tree density of the sample sites $\left(900 \mathrm{~m}^{2}\right)$. The result expectedly shows that shelterbelt sites have higher density compared to the adjacent control sites. The ANOVA result in Table 2 also shows that there is significant difference between the two sites with respect to density $(\mathrm{P}<0.05)$. Annual clearing of the adjacent plot by farmers to make room for crop has also impact negatively on density while restriction by law imposed on the shelterbelt sites would be expected to contribute to increased density. According to the theory of island biogeography, increase in the density of trees creates suitable habitat for wildlife in an area surrounded by hostile and degraded environment thereby increasing biodiversity (Wu and Vankat, 1995; Haila, 2002; Bossuyt et al., 2003). High densities of trees do not only provide shelter and corridor for wildlife but also increase the amount of litter from trees consequently enhancing the soil nutrient status and water infiltration, thereby making the environment more resilient to perturbation as a result of desertification.

Table 3. Characteristics of Tree Density $\left(900 \mathrm{~m}^{2}\right)$

\begin{tabular}{lcrr}
\hline Site & Mean & \multicolumn{1}{c}{ Std. Deviation } & \multicolumn{1}{c}{ Std. Error } \\
\hline JJ1 & 44.8333 & 13.64374 & 3.93861 \\
JJ2 & 59.7500 & 8.79178 & 2.53797 \\
GD1 & 50.4167 & 11.82800 & 3.41445 \\
GD2 & 44.8333 & 18.60515 & 5.37084 \\
JJ1 Cont & 19.5000 & 10.32649 & 2.98100 \\
JJ2 Cont & 11.3333 & 8.52092 & 2.45978 \\
GD1 Cont & 12.0000 & 15.48019 & 4.46875 \\
GD2 Cont & 13.0000 & 13.37569 & 3.86123 \\
\hline
\end{tabular}

\subsection{Species Frequency}

Species frequency is the number of times a plant species appears in a given number of quadrants at a given number of sample points. It is a good measure of biodiversity in an ecosystem (Odum, 1969). The common 
species of the woody genera in the shelterbelt sites are the Azadirachta indica and Acacia spp. with 50 and 46 percent respectively while in the adjacent control plots Hyphaene thebaica, Guiera senegalensis, and Acacia tortilis dominates having 31,12 and 13 percent respectively. The result on species frequency in each sampled site is shown in Table 6. The result of the ANOVA in Table 2 shows that there is significant difference between the shelterbelt and the control sites $(\mathrm{P}<0.05)$. This implies that shelterbelt influences species frequency and abundance. Thus, it helps in distinguishing species composition between sites.

\subsection{Species Diversity}

The number of different species present in a given community determines the species richness of the community. The values of Simpson Index for the sample sites are given in Table 5. The result shows that there is higher diversity in the control sites than the shelterbelt sites. This is because the shelterbelt sites are planted with specific types of species whereas this is not so on the adjacent control sites where plants grow naturally. Furthermore some of the species particularly Azadirachta indica have allelophatic effect on the other plants. The result of Simpson diversity index shows that the two Jajimaji shelterbelt sites have diversity indices of 0.76 and 0.67 while their control sites have the diversity indices of 0.74 and 0.79 . The high species diversity in Jajimaji shelterbelt one (JJ1) is due to the number of species used in establishing the belt. It is the only shelterbelt selected for this study that has all the four shelterbelt species (Azadirachta indica, Acacia spp, Eucalyptus spp and Prosopis juliflora). This increase in number of species used in the shelterbelt has also attracted other native species to the area especially doum palm (hyphaene thebaica). However, the Garanda shelterbelt sites have diversity indices of 0.52 and 0.53 which show a clear difference with that of the control sites that have diversity indices of 0.77 and 0.75 . The ANOVA result of species diversity for the combine sites showed that there was no significant difference between shelterbelt and control sites $(F=4.98 . p>0.05)$. This shows that increase in the number of species use in establishing shelterbelts will also increase the occurrence of native species which subsequently will result in increase species diversity. Thus as species diversity increase, the wellbeing of wildlife is also enhanced as they will have varieties of forages to depend on.

Table 4. Species Diversity

\begin{tabular}{lrrrrrrrr}
\hline Parameters & JJ1 & JJ2 & GD1 & GD2 & JJ1-CONT & JJ2-CONT & GD1-CONT & GD2-CONT \\
\hline Taxa of Species & 12 & 12 & 9 & 11 & 8 & 14 & 11 & 9 \\
Individuals & 538 & 717 & 605 & 538 & 234 & 136 & 94 & 87 \\
Dominance & 0.24 & 0.33 & 0.48 & 0.47 & 0.26 & 0.21 & 0.27 & 0.25 \\
Shannon & 1.78 & 1.40 & 0.85 & 0.97 & 1.61 & 1.96 & 1.70 & 1.70 \\
Simpson (1-D) & $\mathbf{0 . 7 6}$ & $\mathbf{0 . 6 7}$ & $\mathbf{0 . 5 2}$ & $\mathbf{0 . 5 3}$ & $\mathbf{0 . 7 4}$ & $\mathbf{0 . 7 9}$ & $\mathbf{0 . 7 3}$ & $\mathbf{0 . 7 5}$ \\
Evenness & 0.49 & 0.34 & 0.26 & 0.24 & 0.63 & 0.50 & 0.50 & 0.61 \\
Menhinick & 0.52 & 0.45 & 0.37 & 0.47 & 0.52 & 1.20 & 1.14 & 0.96 \\
Margalef & 1.75 & 1.67 & 1.25 & 1.59 & 1.28 & 2.65 & 2.20 & 1.79 \\
Equitability (J) & 0.71 & 0.56 & 0.39 & 0.40 & 0.77 & 0.74 & 0.71 & 0.77 \\
Fisher_alpha & 2.18 & 2.05 & 1.50 & 1.96 & 1.60 & 3.92 & 3.23 & 2.52 \\
Berger-Parker & 0.40 & 0.42 & 0.53 & 0.59 & 0.45 & 0.36 & 0.46 & 0.43 \\
\hline
\end{tabular}

\subsection{Vegetation Ordination}

Ordination techniques are used to describe relationships between species composition patterns and the underlying environmental gradients that influence the patterns. The study reveals that shelterbelt species influenced the occurrence and development of some native species. The ecological relationships between the species in the data set with respect to the first two axes produced with Detrended Correspondence Analysis (DECORANA) are presented in Figure 3 and 4. Many ecological studies carried out in Nigeria have also used similar method in their analysis (Adejuwon and Adesina, 1988; Adejuwon et al., 1989; Adesina, 1988). The species ordination shows a fairly clear grouping of the different species in the sample plots. The shelterbelt species are seen to be grouped in close proximity on the ordination diagram. The establishment of shelterbelts with few species has influenced this pattern of grouping. Shelterbelt species are represented with triangular shape on the ordination diagram which show that Azadirachta indica (AI) and Acacia spp (AS) have closer relationship to E. camaldulensis (EC) than with P. juliflora (PJ). The reason for this pattern of distribution in the 
shelterbelt species is because PJ and EC occur in only one of the four shelterbelt sites (JJ1). The non-shelterbelt species shows less affinity with majority of the native species except few of the species like Adansonia digitata (AD), Piliostigma reticulatum (PR), Guiera senegalensis (GS) and Combretum glutinosum (CG) which show relatively fair association. The other species occur randomly without clear association towards a particular group. Apart from environmental factors, human activities also play a role in shaping the pattern of species distribution found in the area. The control sites of Jajimaji and Garanda shelterbelts show that the two areas are different in terms of species found in the sites. The ordination shows that apart from the shelterbelt species, most of the species were scattered without clustering to either shelterbelt or control sites. This reveals the different environmental requirements by species and furthermore the closeness of some species to shelterbelt sites also shows the influence of shelterbelts on those species. The species used for the analysis are presented in Table 6 .

Table 5. List of the Species and Frequency in Sample sites

\begin{tabular}{lccccccccc}
\hline Species & $\begin{array}{c}\text { Species } \\
\text { Code }\end{array}$ & JJ1 & JJ2 & GD1 & GD2 & $\begin{array}{l}\text { JJ1 } \\
\text { Cont }\end{array}$ & $\begin{array}{c}\text { JJ2 } \\
\text { Cont }\end{array}$ & $\begin{array}{c}\text { GD1 } \\
\text { Cont }\end{array}$ & $\begin{array}{c}\text { GD2 } \\
\text { Cont }\end{array}$ \\
\hline Azadirachta indica & AI & 118 & 277 & 322 & 315 & 0 & 0 & 0 & 0 \\
Acacia spp. & AS & 214 & 302 & 266 & 190 & 0 & 0 & 0 & 0 \\
Prosopis juliflora & PJ & 25 & 10 & 0 & 0 & 0 & 0 & 0 & 0 \\
Eucalyptus camaldulensis & EC & 21 & 0 & 0 & 0 & 0 & 0 & 0 & 0 \\
Hyphaene thebaica & HT & 75 & 48 & 3 & 3 & 105 & 49 & 1 & 0 \\
Bauhinia rufescens & BR & 25 & 24 & 1 & 3 & 5 & 8 & 4 & 3 \\
Piliostigma reticulatum & PR & 11 & 10 & 6 & 12 & 23 & 7 & 7 & 10 \\
Balanites aegyptiaca & BA & 24 & 13 & 3 & 3 & 10 & 4 & 1 & 11 \\
Guiera senegalensis & GS & 21 & 25 & 0 & 0 & 36 & 31 & 0 & 0 \\
Leptadenia spp. & LS & 1 & 0 & 0 & 1 & 1 & 1 & 9 & 15 \\
Anogeissus leiocarpus & AL & 1 & 1 & 0 & 0 & 0 & 1 & 0 & 0 \\
Ziziphus mauritiania & ZM & 0 & 0 & 1 & 6 & 22 & 16 & 8 & 1 \\
Adansonia digitata & AD & 2 & 0 & 1 & 2 & 0 & 1 & 1 & 1 \\
Combretum glutinosum & CG & 0 & 0 & 2 & 2 & 0 & 0 & 1 & 3 \\
Faidherbia albida & FA & 0 & 0 & 0 & 1 & 0 & 5 & 17 & 6 \\
Sclerocarya birrea & SB & 0 & 1 & 0 & 0 & 0 & 4 & 0 & 0 \\
Ziziphus spina cristi & ZS & 0 & 1 & 0 & 0 & 0 & 0 & 0 & 0 \\
Commiphora africana & CA & 0 & 5 & 0 & 0 & 0 & 1 & 0 & 0 \\
Calotropis procera & CP & 0 & 0 & 0 & 0 & 0 & 3 & 2 & 0 \\
Acacia tortilis & AT & 0 & 0 & 0 & 0 & 32 & 5 & 43 & 37 \\
\hline & & & & & & & & & \\
\hline
\end{tabular}




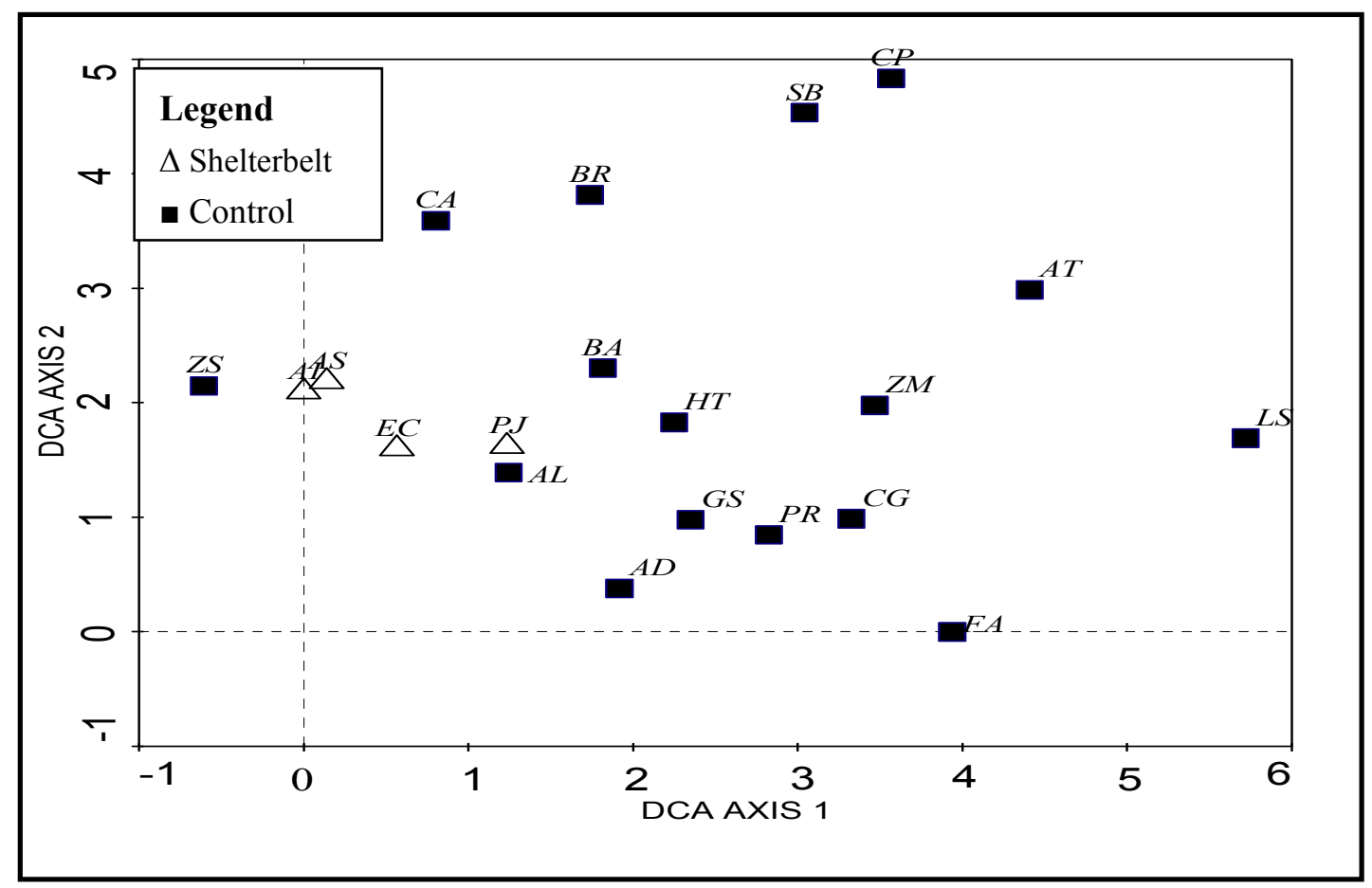

Figure 3. Species Ordination by Detrended Correspondence Analysis (DECORANA)

The sample ordination shows more clear distinction between sample plots (Figure 4). Cluster of plots at the left side shows shelterbelt plots while those on the right show the control plots. Thus, from the sample ordination diagram it is clear that the control sites have two groups of species with similar environmental requirements as defined in the sample ordination diagram. The first axis of the detrended correspondence analysis discriminates the plots well compared with the second axis as the differences are found on the first axis. 


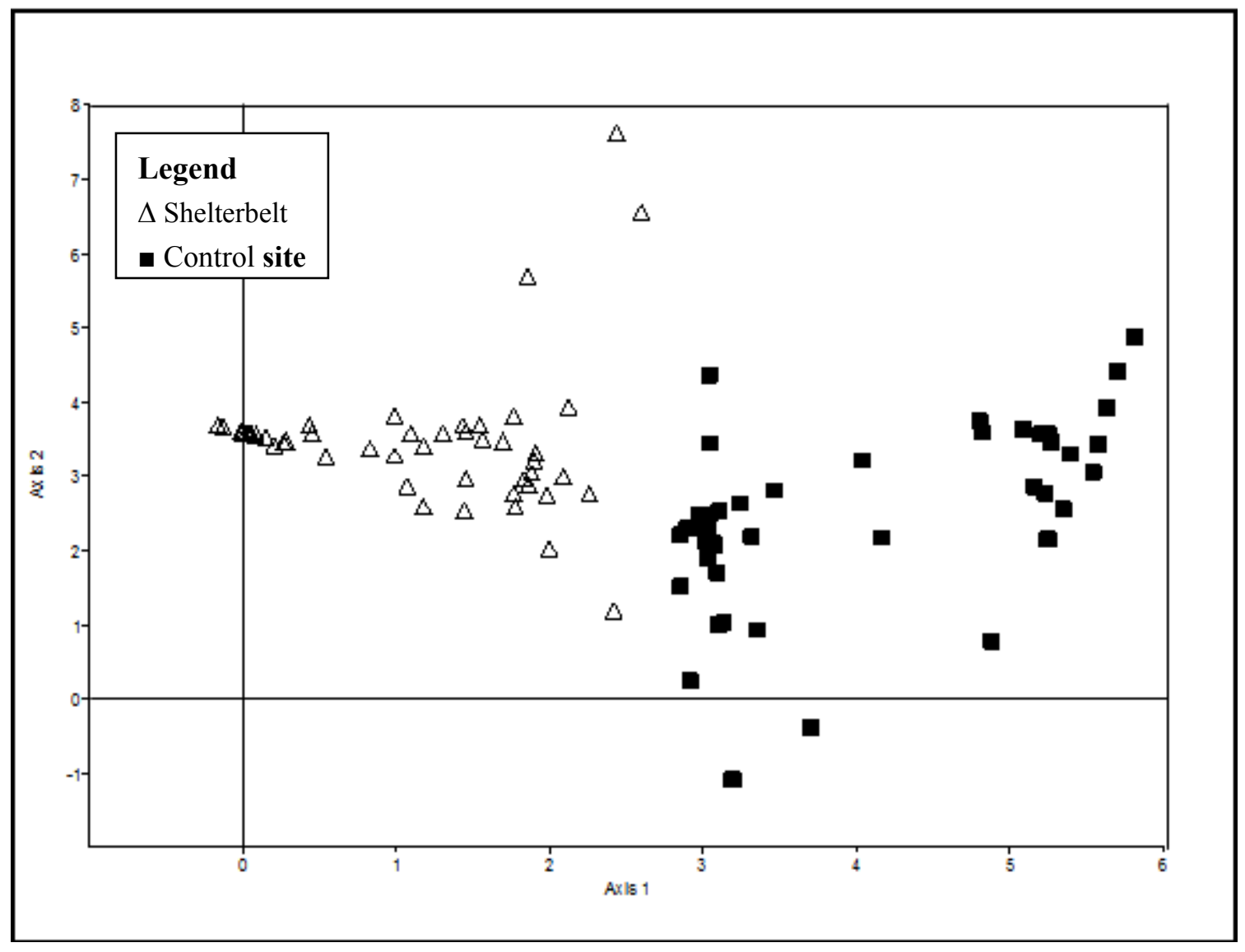

Figure 4. Sample Ordination by Detrended Correspondence Analysis (DECORANA)

\section{Conclusion}

The study revealed that the establishment of shelterbelt has enormous ecological benefits to areas prone to desertification. From the vegetation parameters considered for this study (tree height, tree diameter, tree density, specie frequency and species diversity) it can be concluded that shelterbelts enhances soil fertility, protects soil against wind erosion and improves water percolation in the soil. Such improvements in soil condition consequently result in vegetation development in areas where shelterbelts are established. The study further revealed that human activities as a result of tree felling by herdsmen or fuelwood collectors have greatly reduce the potentials of the natural vegetation on the adjacent sides of the shelterbelt in carrying out their ecological functions. Agricultural activities also limit the occurrence of trees in the study area. These activities included annual clearing of vegetation to create space for crop cultivation and grazing by domestic animals. These activities have negatively affected the status of trees in the region thereby reducing their capacity to check desertification. The result shows that carbon stock of trees in the shelterbelt sites are significantly greater than those in the control sites. This implies that the shelterbelts have higher capacity to sequester carbon dioxide from the atmosphere thereby mitigating the impact of climate change. The DECORANA results show a fairly clear grouping of the different species in the sample plots. This is due to the way shelterbelts are established with fewer species of trees. The shelterbelt species on the ordination diagram show that Azadirachta indica and Acacia spp have closer relationship to E. camaldulensis than with Prosopis juliflora. The non-shelterbelt species shows less affinity only few of the species like Anogeissus leiocarpus, Adansonia digitata, Piliostigma reticulatum, Guiera senegalensis and Balanites aegyptiaca that are found in the bottom-middle portion of the ordination diagram. The sample ordination shows more clear distinction between sample plots of the shelterbelt and the control sites. The study concludes that shelterbelts enhance the development of vegetation status in the area thereby decreasing the impact of some ecological problems associated with desertification and also contributing to a healthier and safe habitat for wildlife. The study recommends that the establishment of shelterbelt be encouraged using more than two types of species in desert prone areas. This is because it increases the diversity and enhances the development of vegetal cover. Further study is needed to ascertain the influence of shelterbelt on the development of vegetation by establishing permanent plots which will help in screening out the effects of 
human activities.

\section{Acknowledgement}

We wish to acknowledge the Nigerian Conservation Foundation (NCF) for the grant given in support of this research and Adamawa State University for their assistance.

\section{References}

Adejuwon, J. O., \& Adesina, F. A. (1988). Vegetation Pattern along the Forest-Savanna Boundary in Nigeria. $\begin{array}{llll}\text { Singapore Journal of Tropical } & \text { Geography, } & 9(1), & \text { 18-32. }\end{array}$ http://dx.doi.org/10.1111/j.1467-9493.1988.tb00193.x

Adejuwon, J. O., Adesina, F. A., \& Onijingin, E. (1989). Some Aspect of Soil and Vegetation recovery in Forest and Savanna fallows in Western Nigeria and their implications for Agricultural development. Malaysian Journal of Tropical Geography, 20, 1-11.

Adesina, F. A. (1988). Plant species characteristics and vegetation dynamics in the Tropics. Intern. J. Environmental Studies, 33, 67-78.

Adesina, F. A. (2008). Living in a severely altered world. An inaugural lecture delivered at Obafemi Awolowo University, Ile-Ife on 28 October 2008.

Ayuba, H. K. (1995). Grazing and land degradation in a semi-arid rangeland in Northeastern Nigeria. Unpublished PhD thesis submitted to Geography Department, University of Ibadan, Nigeria.

Bossuyt, B., Honnay, O., \& Hermy, M. (2003). An Island Biogeographical View of the Successional Pathway in Wet Dune Slacks. Journal of Vegetation Science, 14(6), 781-788. http://dx.doi.org/10.1111/j.1654-1103.2003.tb02210.x

Bovill, E.W. (1921). The encroachment of the Sahara on the Sudan. Journal of the Royal African Society, 20, 175-185, 259-269.

Cao, Y., Ouyang, Z. Y., Zheng, H., Huang, Z. G., Wang, X. K., \& Miao, H. (2007). Effects of Forest Plantations on Rainfall Redistribution and Erosion in the Red Soil Region of Southern China. Land degradation \& development, 19, 321-330.

Cornelis, W. M., \& Gabriels, D. (2005). Optimal windbreak design for wind-erosion control. Journal of Arid Environments, 61, 315-332. http://dx.doi.org/10.1016/j.jaridenv.2004.10.005

Dami, A. (2008). Geographic Information System Based Predictive Study of Environmental Change in the Nigeria's Section of the Chad Basin. Unpublished PhD. Thesis. Obafemi Awolowo University, Ile-Ife, Nigeria.

FAO. (2005). Assessment of the National Forest Programmes in Nigeria. Retrieved December 5, 2009, from http://www.fao.org/DOCREP/005/AC918E/AC918E02.htm

FME. (2008). Managing the Nigerian Environment for Sustainable Development: Challenges and Opportunities. Federal Ministry of Environment, Housing and Urban Development report on the State of the Environment.

Gadiga, B. L. (2012). The Functioning of shelterbelts in Soils and Floristic restoration in the Sudano-Sahelian region of Yobe State, Nigeria, PhD. Thesis. Obafemi Awolowo University, Ile-Ife, Nigeria.

Goodall, D. W. (1954). Objective methods for the classification of vegetation. III. An essay in the use of factor analysis. Australian Journal of Botany, 1, 39-63. http://dx.doi.org/10.1071/BT9540304

Graae, B. J., \& Heskjax, V. S. (1997). A comparison of understorey vegetation between untouched and managed deciduous forest in Denmark. Forest Ecology and Management, 96, 111-123. http://dx.doi.org/ 10.1016/S0378-1127(97)00046-7

Haila, Y. (2002). A conceptual genealogy of fragmentation research: from Island biogeography to landscape $\begin{array}{llll}\text { ecology. Ecological } & \text { Applications, } & \text { 321-334. }\end{array}$ http://dx.doi.org/10.1890/1051-0761(2002)012[0321:ACGOFR]2.0.CO;2

Igboanuga, A. B. I. ()1991. Role of Tree Shelters in the Ameliorating of Arid Environments Production and Human Comfort. In: Dada, G. O. B. and P. C. Obiaga (eds). Development and Management of Forest Resources of the Arid Zone of Nigeria. Proceeding of the $20^{\text {th }}$ Annual Conference of FAN, Katsina, 25-30 $0^{\text {th }}$ November, 1990. pp 45-48.

Igugu, G. O., \& Osemeobo, G. J. (1991). Strategies for Facilitating Shelterbelt Establishment in Nigeria. In Dada, 
G. O. B., \& P. C. Obiaga (Eds.), Development and Management of Forest Resources of the Arid Zone of Nigeria (pp. 198-205). Proceeding of the $20^{\text {th }}$ Annual Conference of FAN, Katsina, 25-30 ${ }^{\text {th }}$ November, 1990.

Mohammed, A. E., Stigter, C. J., \& Adam, H. S. (1996). On shelterbelt design for combating sand invasion. Agriculture, Ecosystems and Environment, 57, 81-90. http://dx.doi.org/10.1016/0167-8809(96)01026-2

Molder, A., Bernhardt-Romermann, M., \& Schmid, W. (2008). Herb-layer diversity in deciduous forests: Raised by tree richness or beaten by beech? Forest Ecology and Management, 256, 272-281. http://dx.doi.org/10.1016/j.foreco.2008.04.012

NAP. (2007). Combating Desertification and Mitigating the Effects of Drought in Nigeria. Report Submitted to UNCCD by Federal Ministry of Environment, Nigeria.

Odigie, G. A., \& Obiaga, P. C. (1991). Afforestation Strategy for Drought and Desertification Control in Nigeria. In Dada, G. O. B., \& Obiaga, P. C. (Eds.), Development and Management of Forest Resources of the Arid Zone of Nigeria (pp 262-269). Proceeding of the $20^{\text {th }}$ Annual Conference of FAN, Katsina, 25-30 November, 1990.

Oguntoyinbo, J. S. (1983). Climate. In Oguntoyinbo, J. S., Areola, O. O., \& Filani, M. A. (Eds.), Geography of Nigerian development (2nd, ed.). Heinemann Educational Books, Ibadan.

Ojo, G. O. A., Onyewotu, L. O. Z., \& Ujah, J. E. (1987). Use and management of shelterbelts. In Sagua, et al. Ecological disasters in Nigeria: Drought and desertification. Proceeding of the National workshop of FAN, Kano, 9-12 December, 1985.

Okefiena, E. A. O. (1988). Establishing Shelterbelts for Desertification Control. In Dada, G. O. B. (Ed.), Proceeding of the 18 $8^{\text {th }}$ Annual Conference of FAN, Markudi, 4-8 December, 1988, 46-49.

Oladipo, E. O. (1993). A comprehensive approach to drought and desertification in Northern Nigeria. Natural Hazards, 8(3), 235-261. http://dx.doi.org/10.1007/bf00690910

Oruonye, E. D. (2009). Geographical aspects of Yobe State, Nigeria. Jos, Fab Education Books.

Pascal, S. (2003). Monitoring vegetation change in the Kosciuszko Alpine zone, Australia. Honours Thesis. School of Environmental and Applied Sciences, Griffith University, Gold Coast.

Szajdak, L., Gaca, W., \& Karg, M. (2005). Impact of the age of Shelterbelts and the Composition of plants on the dissimilatory nitrate reductanse activity in Soils. Polish Journal of Soil Science, 38(2). Pp 135-144.

Torita, H., \& Satou, H. (2007). Relationship between shelterbelt structure and mean wind reduction. Agricultural and Forest Meteorology, 145, 186-194. http://dx.doi.org/10.1016/j.agrformet.2007.04.018

UNDP. (2009). Climate Change in African Drylands: Adaptive Livelihood Options. UNDP-UNEP-UNCCD papers. Retrieved May 2009, from www.undp.org/drylands

UNICED (1992). Managing Fragile Ecosystems: Combating Desertification and Drought. UN Conference on Environment and Development (Earth Summit). Rio de Janeiro, Brazil.

UNESCO. (2000). Combating Desertification: Freshwater Resources and the Rehabilitation of Degraded Areas and Drylands. UNESCO-MAB Drylands Series No.1. Retrieved September 4, 2009, from http://unesdoc.unesco.org/images/ 0012/001276/127651e.pdf

UNEP. (2008). "Africa: Atlas of Our Changing Environment." Division of Early Warning and Assessment (DEWA) United Nations Environment Programme (UNEP)P.O. Box 30552, Nairobi 00100, Kenya

Wang, H., \& Takle, E. S. (1996). On Shelter Efficiency of Shelterbelts in Oblique Wind. Agricultural and Forest Meteorology 81. pp 95-117. http://dx.doi.org/10.1016/0168-1923(95)02311-9

Wu, J., \& J. L. Vankat. (1995). Island biogeography: theory and applications. In: W. A. Nierenberg (ed), Encyclopedia of Environmental Biology, 2, 371-379, Academic Press, San Diego.

\section{Copyrights}

Copyright for this article is retained by the author(s), with first publication rights granted to the journal.

This is an open-access article distributed under the terms and conditions of the Creative Commons Attribution license (http://creativecommons.org/licenses/by/3.0/). 